\title{
Penerapan Metode Praktikum dan Strategi Rotating Trio Exchange (RTE) dalam Meningkatkan Aktivitas dan Hasil Belajar IPA Biologi (Kelas VIII SMP Negeri 1 Jelbuk Tahun Pelajaran 2014/2015) (Implementation of Eksperiment Method and Rotating Trio Exchange Strategy in Improving Activity and Learning Result of Biology Science (Class VIII SMP Negeri 1 Jelbuk Jember Student Academic Year
} 2014/2015))

Friska Oktaviana W.C., Suratno, Sulifah Aprilya H.

Program Studi Pendidikan Biologi, Fakultas Keguruan dan Ilmu Pendidikan, Universitas Jember (UNEJ) Jln. Kalimantan 37, Jember 68121

email : suratno.fkip@unej.ac.id

\begin{abstract}
Abstrak
Hasil observasi awal menunjukkan bahwa guru menggunakan metode ceramah. Metode ini menjadikan guru sebagai pusat pembelajaran sehingga siswa cenderung hanya mendengarkan tanpa adanya stimulus yang mendorong interaksi antar siswa dalam proses pembelajaran. Strategi pembelajaran yang mampu mendorong siswa untuk berinteraksi dan aktif dalam pembelajaran adalah strategi Rotating Trio Exchange (RTE) dan metode praktikum. Tujuan dari penelitian ini adalah untuk meningkatkan aktivitas dan hasil belajar siswa dengan menggunakan metode praktikum dan strategi Rotating Trio Exchange (RTE) pada Mata Pelajaran IPA-Biologi sub bahasan Struktur dan Fungsi Jaringan pada Tumbuhan dan Fotosintesis kelas VIII SMP Negeri 1 Jelbuk Jember. Penelitian ini merupakan penelitian tindakan kelas yang dilaksanakan kolaborasi dalam rangkaian kegiatan (plan, do, dan see). Penelitian ini dilaksanakan sebanyak dua siklus dan masing-masing siklus terdiri dari dua pertemuan. Dalam penelitian ini analisis data yang dilakukan menggunakan analisis deskriptif kualitatif.. Data yang dianalisis pada penelitian ini antara lain aktivitas dan hasil belajar IPA Biologi yang diperoleh dari hasil pembelajaran melalui penerapan metode praktikum dan strategi Rotating Trio Exchange (RTE). Penilaian meliputi penilaian aktivitas siswa, hasil belajar ranah kognitif, psikomotor dan afektif siswa. Hasil analisis menunjukkan bahwa penerapan metode praktikum dan startegi Rotating Trio Exchange (RTE) dapat meningkatkan aktivitas dan hasil belajar siswa. Pada aktivitas bertanya dan menjawab pertanyaan mencapai nilai 85 , bekerjasama 87 , diskusi 90,75 , dan menyampaikan pendapat 81 . Hasil belajar siswa ranah kognitif juga mengalami peningkatan dari rerata nilai 62,5 pada pra siklus mencapai nilai 73 pada siklus I dan 81,15 pada siklus II.
\end{abstract}

Kata kunci : praktikum, strategi RTE, aktivitas, hasil belajar

\section{Abstract}

Result of preliminary observation showed if teacher use lecture method. In this method teacher as learning center so student just listening without any stimulus that encourage student to interact with other student in learning process. The laerning strategy that can encourage student's interaction and active in learning process is Rotating Trio Exchange strategy and experiment method. The purpose of this research is improve student's activities and learning result using the experiment method and Rotating Trio Exchange strategy on sciencebiology topics of structure and plant's tissue function and photosynthesis class VIII SMP Negeri 1 Jelbuk Jember. This study is research in a series class that colaborated on activities (plan, do, and see). The research conducted by two cycle and each cycle consisting of two meetings. This research uses qualitative descriptive analysis as the data analysis. Data analysis in this research is activity and learning result of Biology obtained from application of eksperiment method and Rotating Trio Exchange strategy. Assessment on this research includes student activities, learning outcomes in the cognitive, psychomotor, and affective. Analysis result showed if learning by implementing experiment method and Rotating Trio Exchange strategy can increase activities and student learning result. On activity asking and answer the question achieve value 85, cooporation 87, discussion 90,75, and express the idea 81. Student learning result on cognitive aspect also increase from value mean 62,5 on pra cycle achieve value 73 on first cycle and 81,15 on second cycle.

Keywords : experiment, RTE strategy, activity, learning result

\section{Pendahuluan}

Berdasarkan OECD PISA, (2012) secara global hasil penelitian Program for International Student Assessment
(PISA) pada tahun 2009 menunjukkan bahwas dalam bidang sains, kemampuan siswa Indonesia berada pada peringkat dua dari bawah yang menempatkan Indonesia di posisi 64 dari 65 negara yang berpartisipasi dalam proyek tersebut. 
Hal ini merupakan penurunan dari hasil PISA tahun 2009 dimana saat itu Indonesia menduduki peringkat 57. Demikian pula pada Trends in International Mathematic and Sciense Study (TIMSS) tahun 2011 yang menunjukkan bahwa penguasaan matematika siswa Indonesia kelas delapan SMP berada di peringkat 38 dari 45 negara. Indonesia hanya mampu mengumpulkan 386 poin dari skor rata-rata 500 . Hasil ini juga menunjukkan penurunan dibandingkan tahun 2007, Indonesia mampu mengumpulkan 397 poin. [1]

Hasil observasi awal di SMP Negeri 1 Jelbuk pada pembelajaran Biologi menunjukkan guru menggunakan metode ceramah dimana metode tersebut belum mengarah pada model sehingga pembelajaran menjadi efektif dan siswa dapat berkembang, dinamis, dan kreatif. Guru sebagai sumber belajar, fasilitator, pengelola, pembimbing, evaluator dan motivator harus inovatif serta menggunakan model pembelajaran pembelajaran tertentu. Dalam metode ceramah guru lah yang menjadi pusat pembelajaran sehingga siswa cenderung hanya mendengarkan tanpa adanya stimulus yang mendorong interaksi antar siswa dalam proses belajar mengajar. Aktivitas belajar siswa di dalam kelas seperti melakukan percobaan, bekerja sama dengan siswa lain, diskusi dan menyampaikan pendapat juga sangat rendah. Metode tersebut kurang efektif dilakukan untuk kondisi siswa yang memiliki kesulitan belajar cukup kompleks. Media pembelajaran yang digunakan pun kurang bervariasi, hanya terbatas pada papan tulis. Hasil evaluasi terakhir menunjukkan rata-rata hasil belajar siswa masih dibawah KKM. Hal tersebut dapat dikarenakan dari kurangnya motivasi belajar siswa dan proses pembelajaran yang kurang mendukung siswa untuk aktif.

Permasalahan ini membutuhkan alternatif strategi pembelajaran yang mampu mendorong siswa untuk aktif sehingga pembelajaran menjadi efektif dan siswa dapat berkembang, dinamis, dan kreatif. Guru sebagai sumber belajar, fasilitator, pengelola, pembimbing, evaluator dan motivator harus inovatif serta menggunakan model pembelajaranpembelajaran tertentu. Dalam metode ceramah guru lah yang menjadi pusat pembelajaran sehingga siswa cenderung hanya mendengarkan tanpa adanya stimulus yang mendorong interaksi antar siswa dalam proses belajar mengajar. Aktivitas belajar siswa di dalam kelas seperti melakukan percobaan, bekerja sama dengan siswa lain, diskusi dan menyampaikan pendapat juga sangat rendah. Metode tersebut kurang efektif dilakukan untuk kondisi siswa yang memiliki kesulitan belajar cukup kompleks. Media pembelajaran yang digunakan pun kurang bervariasi, hanya terbatas pada papan tulis. Hasil evaluasi terakhir menunjukkan rata-rata hasil belajar siswa masih dibawah KKM. Hal tersebut dapat dikarenakan dari kurangnya motivasi belajar siswa dan proses pembelajaran yang kurang mendukung siswa untuk aktif.

Permasalahan ini membutuhkan alternatif strategi pembelajaran yang mampu membimbing siswa mengembangkan potensi dan kreatifitas yang dimilikinya. Salah satu stra yang mampu membimbing siswa mengembangkan potensi dan kreatifitas yang dimilikinya. Salah satu strategi yang dapat digunakan adalah Rotating Trio Exchange (RTE).
Rotating Trio Exchange (RTE) merupakan strategi belajar yang memungkinkan siswa untuk melakukan proses belajar secara aktif, dinamis, kreatif, berpartisipasi, bekerjasama dan memecahkan masalah-masalah tertentu berkaitan dengan materi pelajaran. Strategi ini juga mengembangkan sebuah lingkungan belajar yang aktif dengan menciptakan peserta didik bergerak secara fisik untuk berbagi pikiran dan perasaan secara terbuka, serta untuk memperoleh perasaan suka dan bangga. [2]

Berdasarkan karakter siswa SMP yang tinggal di pedesaan dengan berbagai permasalahan internal yang dihadapi, membentuk mereka menjadi pribadi yang aktif dan membangkitkan motivasi untuk belajar bukanlah hal yang mudah. Maka dari itu memilih strategi pembelajaran aktif (active learning) merupakan hal yang sangat dibutuhkan.

Strategi pembelajaran yang aktif dan menyenangkan ini akan menghasilkan capaian yang lebih baik jika digabungkan metode yang sangat mendukung pelajaran Biologi dan dapat mengembangkan keterampilan dasar siswa serta dapat meyakinkan pemahaman siswa, yaitu metode praktikum. Selain itu, praktikum memberi kesempatan kepada siswa untuk memenuhi dorongan rasa ingin tahu dan ingin bisa. Prinsip ini sangat menunjang kegiatan praktikum yang di dalamnya siswa menemukan pengetahuan melalui eksplorasinya terrhadap alam. Keberadaan praktikum ini pun banyak didukung oleh para psikologi belajar, pakar IPA maupun para pakar pendidikan, sekalipun masing-masing meninjau dari sisi yang berbeda tentang manfaat praktikum.

\section{Metode Penelitian}

Jenis penelitian ini adalah Penelitian Tindakan Kelas (PTK). Penelitian tindakan dilaksanakan secara kolaboratif dalam rangkaian kegiatan (plan, do, dan see) menggunakan model Hopkins. Penelitian tindakan kelas dalam model ini terdiri dari empat tahap, meliputi perencanaan, tindakan, observasi dan refleksi. Penelitian dilaksanakan sebanyak dua siklus dengan analisis secara deskriptif kualitatif.

\section{a. Penilaian aktivitas siswa}

- Aktivitas belajar siswa dalam penerapan pembelajaran dengan metode praktikum dan Rotating Trio Exchange (RTE) berorientasi pada pembelajaran biologi dapat diukur dengan menggunakan rumus :

$$
P a=\frac{n}{N} \times 100 \%
$$

Keterangan:

$\mathrm{Pa}:$ peningkatan aktivitas

$\mathrm{n}$ : jumlah skor aktivitas belajar yang diperoleh siswa

$\mathrm{N}$ : jumlah skor aktivitas belajar maksimum. [3]

Untuk mengetahui kategori aspek adalah dengan ketentuan kriteria pada Tabel 1 berikut ini.

Tabel 1. Kriteria Aktivitas Siswa

\begin{tabular}{|c|c|}
\hline Persentase Aktivitas & Kriteria Aktivitas \\
\hline $\mathrm{Pa} \geq 81 \%$ & Sangat Aktif \\
\hline $61 \%<\mathrm{Pa} \leq 80 \%$ & Aktif \\
\hline $41 \%<\mathrm{Pa} \leq 60 \%$ & Cukup Aktif \\
\hline $25 \% \leq \mathrm{Pa} \leq 40 \%$ & Kurang Aktif \\
\hline
\end{tabular}


b. Penilaian Hasil Belajar Siswa

1) Ranah Kognitif

Kriteria Ketuntasan Minimal disesuaikan dengan kebijakan SMP Negeri 1 Jelbuk Jember, ditentukan:

a) Daya serap perorangan, seorang siswa dikatakan tuntas apabila telah mencapai nilai $\geq 70$ dari skor maksimal 100

b) Daya serap klasikal, suatu kelas dikatakn tuntas apabila terdapat $75 \%$ yang telah mencapai nilai $\geq 70$ dari skor maksimal 100

Ketuntasan belajar dilihat dari skor nilai tes yang diperoleh siswa setelah mengikuti pembelajaran biologi menggunakan metode praktikum dan Rotating Trio Exchange (RTE). Untuk mengetahui persentase ketuntasan belajar siswa secara klasikal maka digunakan rumus :

$$
P k=\frac{n}{N} \times 100 \%
$$

Keterangan:

$\mathrm{Pk}$ : persentase ketuntasan secara klasikal

$\mathrm{n}$ : jumlah siswa yang tuntas hasil belajarnya

$\mathrm{N}$ : jumlah seluruh siswa. [4]

2) Ranah Afektif

Penilaian ranah afektif siswa meliputi aktivitas siswa selama proses pembelajaran, yang meliputi aktif bertanya dan menjawab, menghargai pendapat, dan bekerjasama. Untuk mengetahui hasil belajar ranah afektif digunakan rumus :

$$
\text { Nilai }=\frac{\text { skor didapat }}{\text { skor maksimal }} \times 100 \%
$$

3) Ranah Psikomotorik

Apabila hasil yang diperoleh pada hasil ulangan harian selama pelaksanaan pembelajaran pada siklus I belum terdapat $75 \%$ yang telah mencapai nilai $\geq 70$ maka pembelajaran dilanjutkan ke siklus II dengan melakukan tahapan plan, do, dan see. Siklus II dapat dianggap sebagai siklus terakhir dalam penelitian ini. Hasil ulangan harian antara siklus I dan siklus II akan dibandingkan kemudian dapat digunakan untuk mengetahui tingkat pencapaian hasil belajar siswa. Hasil angket aktivitas siswa dibandingkan dari pra siklus II untuk mengetahui besarnya peningkatan setiap aspek aktivitas dari seluruh siswa yaitu apabila mengalami peningkatan dari kategori tidak aktif atau kurang aktif menjadi kategori aktif, dan sangat aktif.

\section{Hasil dan Pembahasan}

Berdasarkan hasil analisis menunjukkan bahwa penerapan metode praktikum dan strategi Rotating Trio Exchange (RTE) dapat meningkatkan aktivitas siswa dan hasil belajar siswa. Peningkatan aktivitas siswa dari hasil observasi dari pra siklus I ke siklus II. Dari Tabel 2 dapat diketahui bahwa rata-rata aktivitas belajar siswa terus mengalami peningkatan. Rata-rata aktivitas belajar siswa pada pra siklus ialah 1,87 sehingga termasuk dalam kategori cukup aktif. Pada siklus I, rata-rata aktivitas belajar siswa meningkat menjadi 2,83 dan termasuk dalam kategori aktif.
Tabel 2. Aktivitas belajar siswa pada pra siklus, siklus I dan siklus II

\begin{tabular}{|l|l|c|c|c|}
\hline No & Kriteria & Pra Siklus & Siklus I & Siklus II \\
\hline 1 & Bertanya/Menjawab & 1.93 & 2.75 & 3.4 \\
\hline 2 & Bekerjasama & 1.87 & 2.83 & 3.48 \\
\hline 3 & Diskusi & 1.6 & 3.14 & 3.63 \\
\hline 4 & $\begin{array}{l}\text { Menyampaikan } \\
\text { Pendapat }\end{array}$ & 2.09 & 2.6 & 3.24 \\
\hline \multicolumn{2}{|l|}{ Rata-rata } & 1.87 & 2.83 & 3.43 \\
\hline
\end{tabular}

Rata-rata aktivitas belajar siswa kembali mengalami peningkatan pada siklus II menjadi 3,43 dan termasuk dalam kategori sangat aktif. Dari hasil analisis data tersebut, terjadi peningkatan rata-rata aktivitas belajar siswa dari siklus I hingga siklus II sebesar 1,17. Aktivitas bertanya dan menjawab pertanyaan, bekerjasama, berdiskusi dan menyampaikan pendapat mengalami peningkatan yang baik antara siklus I dan siklus II. Aktivitas bertanya dan menjawab pertanyaan pada siklus I sebesar 2,75 dan mengalami kenaikan pada siklus II mencapai 3,4. Sedangkan aktivitas bekerjasama pada siklus I sebesar 2,83 dan mengalami kenaikan pada siklus II mencapai 3,48. Aktivitas berdiskusi pada siklus I sebesar 3,14 dan mengalami kenaikan pada siklus II menjadi 3,63. Untuk aktivitas menyampaikan pendapat pada siklus I sebesar 2,6 dan mengalami kenaikan pada siklus II menjadi 3,24. Agar lebih memperjelas, peningkatan rata-rata aktivitas belajar siswa dapat dilihat pada Gambar 1. Sedangkan hasil belajar kognitif siswa pada pra siklus ke siklus I ke siklus II dapat dilihat pada Tabel 3.

Tabel 3. Hasil belajar kognitif siswa pada pra siklus ke siklus I ke siklus II

\begin{tabular}{|l|r|r|r|r|}
\hline Tahap & Nilai & Jumlah & Persentase & Rata-rata \\
\hline Pra siklus & $<70$ & 21 & 63,63 & 62,5 \\
& $>70$ & 12 & 36,36 & \\
\hline Siklus I & $<70$ & 7 & 21,21 & 73 \\
& $>70$ & 26 & 78,78 & \\
\hline Siklus II & $<70$ & 3 & 9,09 & 81.15 \\
\hline \multicolumn{2}{|l|}{$>70$} & 30 & 90,90 & \\
\hline Peningkatan pra siklus ke siklus I & 39.39 & 10.5 \\
\hline Peningkatan siklus I ke siklus II & 12.12 & 8.15 \\
\hline
\end{tabular}

Hasil analisis Tabel 3 menunjukkan terjadi peningkatan antara kegiatan siklus I dan kegiatan siklus II yaitu sebesar $42,42 \%$ atau meningkat sebanyak 14 siswa yang mengalami ketuntasan belajar. Jumlah siswa yang tuntas pada pra siklus sebanyak 12, pada siklus I menjadi 26 siswa dan meningkat menjadi 30 siswa pada siklus II. Persentase ketuntasan hasil belajar pada siklus II ini sebesar 90,90\% sehingga telah memenuhi kriteria ketuntasan hasil belajar klasikal yang ditetapkan sekolah yakni sebesar $\geq 75 \%$ siswa telah mencapai nilai $\geq 70$ (tuntas).

Pengaruh metode praktikum dan strategi Rotating Trio Exchange (RTE) terhadap aktivitas siswa dapat diperoleh 
melalui hasil observasi dengan melihat keaktifan siswa selama kegiatan pembelajaran. Aktivitas yang diamati adalah aktivitas bertanya dan menjawab pertanyaan, bekerjasama, diskusi, dan menyampaikan pendapat. Adapun hasil yang didapat pada penilaian ranah afektif pada siswa kelas VIII A mengalami peningkatan dari tiap siklus.

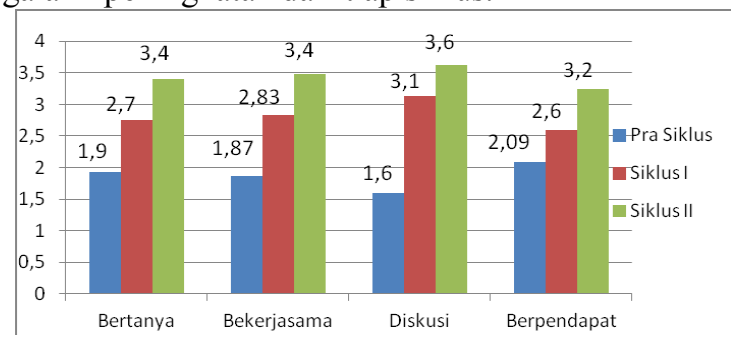

Gambar 1. Histogram rata-rata aktivitas belajar siswa

Aktivitas siswa dengan menggunakan metode praktikum dan strategi Rotating Trio Exchange (RTE) cenderung baik. Metode ini dapat menggugah kemampuan belajar siswa dan membuat proses belajar menjadi menyenangkan dan memuaskan [5]. Dalam penerapan metode ini siswa tidak sekedar mendengar dan memperhatikan penjelasan guru, tetapi siswa juga dituntut melakukan aktivitas gerak/psikomotorik.

Secara keseluruhan rata-rata aktivitas belajar siswa mengalami peningkatan dari pra siklus ke siklus I dan siklus I ke siklus II. Peningkatan aktivitas belajar siswa terjadi karena siswa dilibatkan secara aktif dalam kegiatan pembelajaran menggunakan metode praktikum dan strategi Rotating Trio Exchange (RTE). Dalam setiap proses pembelajaran guru membimbing dan memantau siswa terutama pada kegiatan praktikum, guru senantiasa mendorong siswa untuk dapat melakukan percobaan sesuai arahan yang diberikan oleh guru dan langkah kerja yang terdapat dalam lembar kerja siswa. Selain mendampingi siswa melakukan percobaan dan diskusi dari satu kelompok ke kelompok lainnya, guru juga memberikan bimbingan kepada seluruh siswa di kelas. Hal ini dilakukan agar siswa dapat aktif bertanya dan memberikan pendapat yang dapat mendorong siswa lain untuk ikut berpartisipasi dalam proses pembelajaran.

Penerapan metode praktikum dan strategi Rotating Trio Exchange (RTE) selain untuk meningkatkan aktivitas belajar siswa juga untuk meningkatkan hasil belajar siswa. Menurut Suryosubroto (1997:53) untuk menentukan ketercapaian tujuan pendidikan dan pengajaran perlu dilakukan penilaian hasil belajar [6]. Ketuntasan hasil belajar siswa mencakup tiga ranah, yaitu ranah kognitif, ranah afektif, dan ranah psikomotor. Ranah kognitif berkaitan dengan kemampuan intelektual seseorang; sedangkan ranah afektif berkaitan dengan kemampuan yang berkenaan dengan sikap, nilai perasaan dan emosi; dan ranah psikomotor berkaitan dengan kemampuan yang menyangkut gerakangerakan otot. Pada penerapan metode praktikum dan strategi Rotating Trio Exchange (RTE) ini, ranah yang diamati mencakup ketiga ranah penilaian tersebut, yaitu ranah kognitif, ranah afektif, dan ranah psikomotor.

Berdasarkan data yang diperoleh pada siklus I menunjukkan bahwa terdapat peningkatan hasil belajar siswa menggunakan metode praktikum dan strategi Rotating Trio
Exchange (RTE). Pada pra siklus ketuntasan hasil belajar siswa dari aspek kognitif hanya sebesar $36,36 \%$. Pada siklus I ketuntasan hasil belajar aspek kognitif menjadi 78,78\%. Pada siklus II ketuntasan hasil belajar siswa aspek kognitif menjadi 90\%. Dari hasil tersebut, maka terjadi peningkatan ketuntasan hasil belajar siswa aspek kognitif dari pra siklus ke siklus II meningkatkan sebanyak 53,64\%.

Peningkatan ini dipengaruhi oleh metode praktikum dan strategi Rotating Trio Exchange (RTE) yang diterapkan dalam pembelajaran. Metode praktikum dapat menunjang siswa dalam memahami materi pelajaran (Kholid, 2010). Hal ini karena siswa dituntut untuk melakukan percobaan, pengamatan, dan diskusi berkaitan dengan materi dan percobaan yang telah dilakukan bersama siswa lain dalam kelompok. Melalui serangkaian kegiatan yang dilakukan siswa dalam pelaksanaan metode ini banyak konsep dan materi pembelajaran dapat terbentuk dalam pikiran siswa. Selain itu dengan melakukan kegiatan pengamatan siswa akan lebih mudah mengingat dan memahami materi yang diajarkan kepada siswa.

Strategi Rotating Trio Exchange (RTE) dapat memungkinkan siswa untuk melakukan proses belajar secara aktif, bukan hanya aktif bergerak sesuai prosedur pelaksanaan strategi Rotating Trio Exchange (RTE), tetapi siswa juga dapat secara aktif bekerja sama dan memecahkan masalah-masalah tertentu yang berkaitan dengan materi (Silberman, 2009: 86). Strategi ini menjadikan siswa terbiasa untuk menjawab dan menyelesaikan soal/pertanyaan yang diberikan oleh guru sehingga siswa lebih mudah memahami materi. Penggabungan metode praktikum dan strategi Rotating Trio Exchange (RTE) dapat mendorong siswa untuk memperoleh perasaan suka dan senang dalam mengikuti proses pembelajaran. Hal ini sangat dibutuhkan khususnya dalam pembelajaran biologi yang banyak teori dan siswa harus menghafal/memahami banyak konsep. Oleh karena itu ketuntasan hasil belajar siswa pada aspek kognitif mengalami peningkatan dengan menerapkan metode praktikum dan strategi Rotating Trio Exchange (RTE) dalam pembelajaran.

Berdasarkan data yang diperoleh pada siklus I menunjukkan bahwa terdapat peningkatan hasil belajar siswa menggunakan metode praktikum dan strategi Rotating Trio Exchange (RTE). Pada pra siklus ketuntasan hasil belajar siswa dari aspek kognitif hanya sebesar 36,36\%. Pada siklus I ketuntasan hasil belajar aspek kognitif menjadi 78,78\%. Pada siklus II ketuntasan hasil belajar siswa aspek kognitif menjadi 90\%. Dari hasil tersebut, maka terjadi peningkatan ketuntasan hasil belajar siswa aspek kognitif dari pra siklus ke siklus II meningkatkan sebanyak 53,64\%.

Selanjutnya, aspek yang diamati dalam proses pembelajaran yakni ranah psikomotor. Aspek yang dinilai pada ranah psikomotor tersebut meliputi keterampilan menyiapkan alat dan bahan praktikum, mengikuti arahan guru, melakukan pengamatan, mempraktekkan prosedur kerja dan mengembalikan alat praktikum. Aspek keterampilan yang memiliki rata-rata paling tinggi yakni menyiapkan alat dan bahan praktikum sebesar 3,46\%. Hasil tersebut menunjukkan bahwa siswa tertarik dan memiliki kesiapan awal yang baik untuk mengikuti kegiatan praktikum. Mengikuti arahan yang diberikan oleh guru 
selama melaksanakan kegiatan praktikum sangat penting untuk diperhatikan agar siswa dapat melaksanakan percobaan dengan benar dan tujuan pelaksanaan praktikum dapat tercapai. Melakukan pengamatan harus dilakukan oleh setiap siswa karena dengan melakukan pengamatan siswa akan mendapatkan informasi dan pengetahuan yang dapat menambah pemahaman terhadap materi pembelajaran. Selanjutnya, mempraktekkan prosedur merupakan suatu langkah yang harus diperhatikan dalam pelaksanaan kegiatan praktikum karena hanya dengan mempraktekkan prosedur kerjalah kegiatan praktikum dapat berlangsung. Setelah kegiatan praktikum usai dilaksanakan, hal yang harus dilakukan siswa adalah mengembalikan alat praktikum pada tempat semula atau meletakkan alat praktikum pada tempat yang aman sehingga alat tidak pecah/rusak dan tidak membahayakan siswa.

Selain hasil belajar ranah kognitif dan psikomotor, analisis data juga dilakukan terhadap hasil belajar ranah afektif. Pada ranah afektif siswa juga mengalami peningkatan di setiap pertemuan, pada siklus I pertemuan pertama terdapat 5 siswa yang mendapat nilai $\mathrm{C}$ dan 12 siswa mendapatkan nilai B sedangkan 16 lainnya mendapatkan nilai A. Pada pertemuan kedua siklus I sebanyak 14 siswa mendapatkan nilai B dan 19 siswa mendapatkan nilai A. Siklus II pertemuan pertama diketahui 8 siswa mendapatkan nilai $\mathrm{B}$ dan 25 siswa lainnya mendapatkan nilai $\mathrm{A}$, untuk siklus II pertemuan kedua mengalami peningkatan yaitu seluruh siswa mendapatkan nilai A pada rentang $8 \mathrm{I} \%$ $100 \%$.

Aspek yang dinilai pada ranah afektif tersebut meliputi rasa ingin tahu, percaya diri, memperhatikan penjelasan guru, dan menghargai pendapat. metode praktikum dan strategi Rotating Trio Exchange (RTE) juga dapat meningkatkan afektif siswa. Aspek rasa ingin tahu siswa meningkat saat mengikuti proses pembelajaran terutama saat melaksanakan kegiatan praktikum, siswa terlihat antusias mendengarkan penjelasan guru tentang percobaan yang dilakukan dan aktif bertanya kepada guru. Aspek percaya diri juga diterapkan dalam pembelajaran, hali ini dilihat dari sikap siswa yang tegas,tenang dan tidak terbata-bata dalam menjawab pertanyaan dan menyampaikan pendapat. Selain aspek menyampaikan pendapat yang termasuk dalam penilaian aktivitas siswa, aspek menghargai juga diamati dalam ranah afektif. Hal ini diterapkan agar siswa terbiasa untuk mendengarkan dan meperhatikan pendapat yang disampaikan oleh siswa lain sehingga siswa mendapatkan informasi yang lebih banyak terkait dengan materi pembelajaran.

Ketuntasan hasil belajar ranah kognitif, ranah afektif, dan ranah psikomotor pada siklus II tersebut telah memenuhi kriteria ketuntasan klasikal yang ditetapkan sekolah, sehingga pelaksanaan tindakan pembelajaran dapat dihentikan. Dengan adanya peningkatan hasil belajar setelah pelaksanaan tindakan mengindikasikan bahwa penerapan metode praktikum dan strategi Rotating Trio Exchange (RTE) dapat meningkatkan hasil belajar siswa kelas VIII A.

Keberhasilan dalam proses pembelajaran bukan hanya semata-mata dikarenakan oleh guru, namun juga siswa yang terlibat dalam pembelajaran. Hal tersebut didukung oleh pendapat Sardiman (2005: 145) yang mengemukakan bahwa salah satu peran guru dalam proses pembelajaran sebagai fasilitator dan motivator [7]. Guru berperan sebagai fasilitator yaitu guru dalam hal ini memberikan fasilitas atau kemudahan dalam proses belajar mengajar, misalnya dengan menciptakan suasana kegiatan belajar yang sedemikian rupa, serasi dengan perkembangan siswa sehingga interaksi belajar mengajar akan berlangsung secara afektif. Peranan guru sebagai motivator dalam pembelajaran adalah guru harus dapat merangsang dan memberikan dorongan serta kekuatan untuk menumbuhkan swadaya (aktivitas), dan daya cipta (kreativitas) sehingga akan terjadi dinamika dalam proses belajar mengajar.

Hasil wawancara dengan guru mata pelajaran dan sebagian siswa setelah pelaksanaan tindakan menunjukkan bahwa siswa lebih aktif dan antusias dalam mengikuti proses pembelajaran di kelas. Dengan adanya kegiatan praktikum dapat membuat siswa tertarik untuk mengikuti setiap tahap pembelajaran. Selain itu, kegiatan diskusi kelompok membantu siswa untuk dapat bekerjasama dengan anggota kelompok untuk memecahkan permasalahan yang diberikan.

Secara keseluruhan, hasil penelitian yang telah dilakukan menunjukkan bahwa penerapan metode praktikum dan strategi Rotating Trio Exchange (RTE) pada pembelajaran IPA-biologi materi struktur dan fungsi jaringan pada tumbuhan dan materi fotosintesis dapat meningkatkan aktivitas dan hasil belajar siswa kelas VIII A SMP Negeri 1 Jelbuk tahun ajaran 2014/2015. Hal tersebut membuktikan bahwa metode dan strategi pembelajaran ini dapat dipergunakan sebagai alternatif untuk menyelesaikan permasalahan di kelas khususnya pembelajaran IPA-biologi.

\section{Kesimpulan dan Saran}

Berdasarkan hasil dan pembahasan pada bab sebelumnya, dapat diperoleh kesimpulan sebagai berikut.

Terdapat peningkatan aktivitas belajar siswa kelas VIII A SMP Negeri 1 Jelbuk pada materi materi struktur dan fungsi jaringan pada tumbuhan dan materi fotosintesis menggunakan metode praktikum dan strategi Rotating Trio Exchange (RTE) yaitu sebagai berikut: bertanya dan menjawab pertanyaan siklus I $(68,75)$, siklus II (85) meningkat sebesar 16,25 (sangat aktif); bekerjasama siklus I (70,75) siklus II (87) meningkat sebesar 16,25 (sangat aktif); diskusi siklus I $(78,5)$, siklus II $(90,75)$ meningkat sebesar 12,25 (sangat aktif); dan menyampaikan pendapat siklus I(65), siklus II (81) meningkat sebesar 16 dengan kategori aktif.

b. Terdapat peningkatan hasil belajar klasikal siswa kelas VIII A SMP Negeri 1 Jelbuk pada materi materi struktur dan fungsi jaringan pada tumbuhan dan materi fotosintesis menggunakan metode praktikum dan strategi Rotating Trio Exchange (RTE) mengalami peningkatan $53,64 \%$ dari pra siklus sebesar $36,36 \%$ (12 siswa tuntas) dengan rerata nilai 62,5 dan pada siklus I menjadi $78,78 \%$ (26 siswa tuntas) dengan rerata nilai 73 sedangkan pada siklus II meningkat menjadi 90\% (30 siswa) dengan rerata nilai 81,15 .

Saran yang dapat diberikan setelah mmelakukan penelitian ini adalah pembelajaran dengan menggunakan metode praktikum dan strategi Rotating Trio Exchange (RTE) dapat digunakan untuk melibatkan penilaian dari 
ranah kognitif, afektif, dan psikomotor dan dapat dijadikan alternatif dalam pembelajaran biologi.

\section{Ucapan Terima Kasih}

Paper disusun untuk memenuhi syarat memperoleh gelar sarjana (S1) pada Program Studi Pendidikan Biologi, Universitas Jember. Penulis mengucapkan terima kasih kepada dosen pembimbing tugas akhir yang telah banyak meluangkan waktu sehingga terselesainya penelitian ini.

\section{Daftar Rujukan}

[1] Balitbang. 2012. Survei Internasional TIMSS. [serial online] http:// litbang.kemdikbud.go.id/detail.php?id [28 April2014].

[2] Silberman, Mell. 2009. Active Learning 101 Strategi Pembelajaran Aktif. Yogyakarta: PT. Pustaka Insani Madani.

[3] Slameto. 1999. Bimbimgan di Sekolah. Jakarta: Bina Aksara.

[4] Arikunto. 2010. Prosedur Penelitian Suatu Pendekatan Praktik. Jakarta: Rineka Cipta.

[5] Kholid, S.F. 2010. Metode Pembelajaran Praktikum untuk Meningkatkan Pemahaman Siswa pada Mata Pelajaran Multimedia di Sekolah Menengah Kejuruan. [serial online]. sc.upi.edu/upload/paper. skripsi dik/setiafurqon.pdf. [28 April 2014].

[6] Suryosubroto. 1997. Proses Belajar Mengajar di Sekolah. Jakarta: Rineka Cipta.

[7] Sardiman. 2005. Interaksi dan Motivasi Belajar Mengajar. Jakarta: PT. Raja Grafindo Persada.

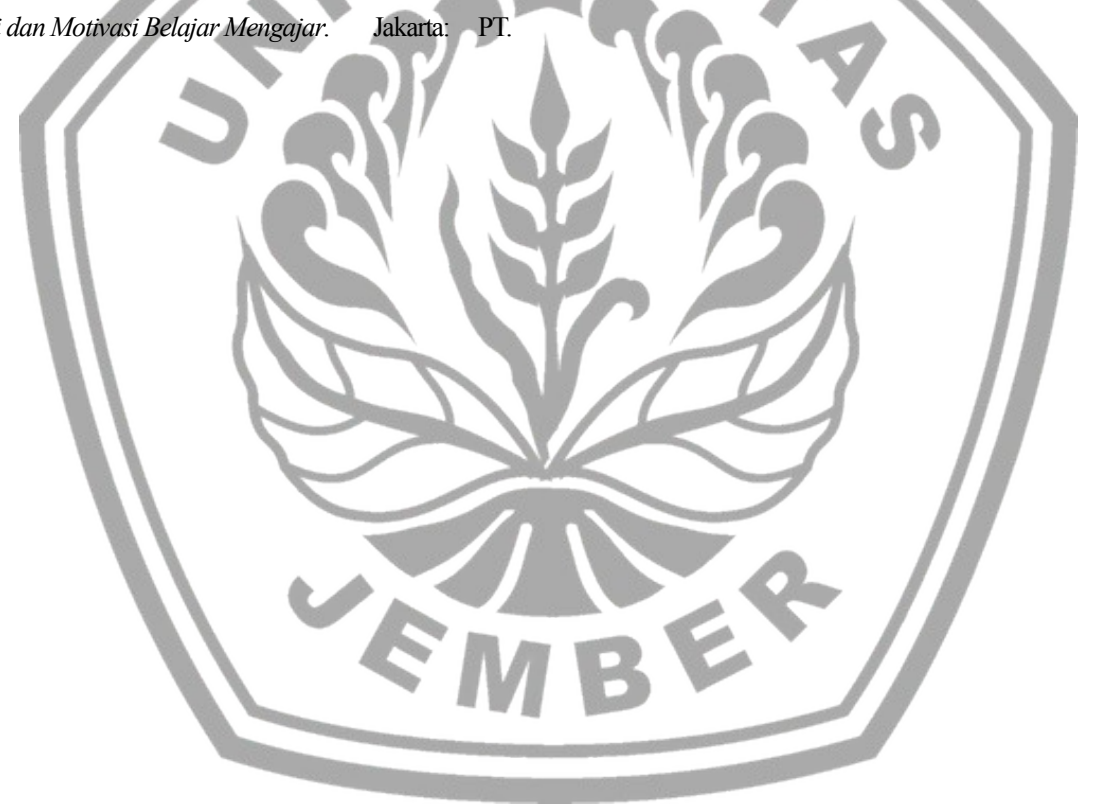

